report for 1966-67. He says that the results have been small scale of operation, swamping by foreign varieties in several crops, the absence, or near absence, of serious commercial effort, and consequently, poor service to the British farmer. Mr Simmonds says that much good science has been done in Britain, for example, on genetic studies, but it is likely that the continental or American breeders will profit from the research, and Britain will find itself paying royalties on the products of its own inventions. If these fundamental studies are to be put to use, a sustained and applied effort will be required.

In his view, the passing of the Seeds Act (1964) was a crucial event followed by the introduction under the act of schemes relating to the various crops. The act makes it possible for breeders to levy royalties on their own varieties in commercial cultivation and should stimulate commercial plant breeding in Britain. If this fails, then there would have to be a great expansion of state breeding. If the act does succeed, $\mathrm{Mr}$ Simmonds thinks that the official breeding stations will be pressed in two directions-partly towards fundamental studies and partly towards breeding crops which are not commercially attractive to the breeders. Mr Simmonds thinks the suggestion that the fundamental studies should be adapted to the universities is wrong in that the studies demand facilities such as land, glasshouses and assistants which could rarely be achieved by British universities, and the studies are basically economic in orientation and would therefore be regarded as "impure" in university circles.

\section{More Accidents}

THE number of accidents in British factories and at building sites rose again last year, according to the Annual Report of the Chief Inspector of Factories (HMSO, 12s. 6d.). The increase was less than over the previous two years, but the fact that almost 300,000 people were injured and that fatal accidents increased from 627 to 701 can be pleasing to no one. The number of workers under eighteen involved in accidents did, however, fall slightly, from 18,200 to 17,400 .

The Chief Inspector, Mr R. K. Christy, emphasizing the need for safety consciousness in industry, said that every establishment should have a trained safety officer, and that managers should plan for safety just as they plan their production or research and development. More specific recommendations are contained in a chapter concerned with the electrical industry in which, however, the accident rate of 25.9 per 1,000 workers is comparatively low. A new testing service is to be set up by the Ministry of Technology to certify the safety of electrical equipment used in flammable atmospheres.

Some interesting comparisons can be made between accident rates in various types of industry. Working in a jute factory, for example, appears to be dangerous: 61 workers in every thousand were involved in an accident last year, twice as high a rate as that in the cotton spinning industry, and nine times as high as that in the manufacture of stockings and knitwear. Or again, there were ten accidents per thousand workers in office machine factories, but the rate was thirty-five among those working on electrical domestic appliances. How can it be so much safer to make a typewriter than an iron, a duplicator than a washing machine? And an inherently dangerous occupation like the manu- facture of explosives is, in fact, roughly four times as safe as working in a brickworks. Even more mysterious is the incidence of accidents in certain regions. In the Sheffield area, 63 in every thousand workers are injured; the figures for Birmingham and Nottingham are 25 and 28. The inspectorate cannot explain this, and comes to the conclusion that "numbers of reported accidents by themselves are not a reliable guide to accident prevention performance". It would be interesting to know if large establishments give more consideration to safety than small ones, and if the large number of accidents in the building industry $(45,600$, of which 288 were fatal) is due as much to this cause as to the nature of the work.

The report also discusses the difficulty of classifying and enumerating accidents. At present an accident is described as an injury that disables a person from working for three days. It is the duty of the employer to inform the inspectorate on the fourth day after the injury, but the extent of the injury may not then be clear. A system of classification based on the hours of work lost will not distinguish between restricted, but permanent, injuries, such as the loss of a finger, and general, but temporary, injuries, such as a badly sprained back. More than three-quarters of all the accidents that happened resulted in cuts, abrasions and strains. It is difficult to say how serious these injuries were, or how easily they could have been avoided.

The report does give details of the causes of fatal accidents. Of the 372 fatal accidents in industry, 95 involved a clear breach of the law by the occupier of the factory, and only 6 by the worker himself. In building, of the 288 deaths, 160 were caused by the employers breaking the law, 22 by the worker. The introduction of highly technical processes and sophisticated plant seems to be an unimportant factor in the increase in the number of accidents. "There is little evidence to suggest that industry is inadequately equipped to deal with the hazards that technological changes may involve; there is, however, abundant evidence to show that in some factories the most obvious dangers continued to be ignored."

\section{The Sutton Hoo Ship}

The British Museum has reopened the excavation of the Sutton Hoo ship and in the next decade hopes also to open the twelve remaining royal graves at the site on the banks of the Deben in Suffolk. When the museum began preparing a four volume definitive description of the Sutton Hoo burial ship so many questions arose that it decided to re-excavate the site.

The original discovery of the ship and its priceless treasures was made in 1939 and with the greatest generosity the landowner Mrs Edith Pretty gave the treasure to the nation; it is now in the British Museum. Mrs Pretty initiated the first excavation and when the complexity of the mound and richness of the treasure were realized MrCharles Phillips, a Cambridge archaeologist, was invited to take over the excavation and handle the emergency. Considering the imminence of the Second World War and the lack in Britain of any archaeologist with experience of such a rich and complex site, the operation was remarkably successful. Unfortunately, however, at the end of the dig the site was, with lack of foresight, written off as of no further value. No effort was made to cover the ship, which was filled 